\title{
Pola Asuh Ibu dan Status Gizi Balita
}

\author{
Masita $^{1}$, Marwati Biswan ${ }^{2}$, Erlin Puspita ${ }^{3}$ \\ Dosen Jurusan Kebidanan Poltekkes Kemenkes Jakarta I \\ Email : erlinpuspita@gmail.com
}

\begin{abstract}
Abstrak
Keadaan gizi balita merupakan salah satu tolak ukur keberhasilan pembangunan kesehatan, oleh sebab itu gizi balita perlu diperhatikan. Pemerintah telah melaksanakan kegiatan perbaikan gizi keluarga yang dikenal dengan Applied Nutrition Program atau Program Usaha Perbaikkan Gizi Keluarga (UPGK) yang memberikan pendidikan gizi praktis kepada keluarga melalui pemantauan pertumbuhan balita di posyandu, dan paket pelayanan kesehatan dasar secara menyeluruh. Faktor yang mempengaruhi status gizi dapat dibedakan atas faktor langsung dan tidak langsung. Faktor langsung ditentukan oleh asupan makanan dan penyakit infeksi, sedangkan faktor tidak langsung meliputi ketersedian makanan dalam keluarga, pola asuh anak, pelayanan kesehatan dan kondisi lingkungan. Tujuan: penelitian untuk mengetahui hubungan antara pola asuh ibu dengan status gizi balita dengan variabel terikat status gizi balita dan variabel bebas pola asuh ibu yang meliputi praktik cara memberi makan, cara merawat balita, praktik kebersihan ibu dan balita serta variabel luar meliputi pendidikan, pekerjaan,status ekonomi dan pendidikan ibu. Metode: penelitian menggunakan rancangan cross sectional dan dilaksanakan di Puskesmas Kecamatan Pancoran Mas Kota Depok pada bulan Juni 2011. Sampel adalah 119 ibu yang mempunyai balita dengan pengambilan data dilakukan secara langsung menggunakan kuesioner. Hasil: analisis multivariabel menunjukkan terdapat hubungan yang bermakna antara praktik merawat balita dengan status gizi. Ibu yang praktik merawat balita kurang baik memiliki risiko 2 kali terhadap kejadian status gizi kurang pada balita. Kesimpulan bahwa praktik merawat balita dan pengetahuan ibu berpengaruh terhadap status gizi balita.
\end{abstract}

Kata Kunci : Status Gizi Balita dan Pola Asuh

\begin{abstract}
Nutritional state of toddler is one measure of the success of health development, therefore nutrition of toddler need attention. The government has been carrying out activities to improve family
\end{abstract}

nutrition known as the Applied Nutrition Program or the Family Nutrition Program Improvement Effort which provides practical nutrition education to families through the monitoring of infant growth in integrated posyandu, and a whole basic health care package. Factors affecting nutritional status can be distinguished on direct and indirect factors. Direct Factor determined by dietary intake and infectious disease, while the indirect factors include the availability of food in the family, child care, health care and environmental conditions. The purpose: of the study to determine the relationship between parenting mothers with nutritional status of toddler, with dependent variable is nutritional status of children and the independent variables included maternal parenting practices how to feed, how to care for infants, mothers and toddlers hygiene practices as well as external variables include education, employment, economic status and mother's education. Method: uses a cross-sectional study carried out in health center sub-district of Pancoran Mas Depok in June 2011. Samples were mothers with toddlers and collected directly by using the questionnaire. Result: Multivariatble analysis showed a significant relationship between the practice of caring for infants with nutritional status. The mothers who had a bad practice of care for a toddler will have the risk 2 times on incidence of poor nutritional status in infants. In conclusions, the practice of caring for infants and mother knowledge affect the nutritional status of toddler. Statistically there is no significant association between feeding practices, hygiene practices of mothers and infants, maternal education, maternal employment and economic status on the incidence of malnutrition.

Keywords: Nutritional Status of Toddler And Parenting

\section{Pendahuluan}

Wanita sebagai ibu dan lingkungan sangat berperan bagi pertumbuhan dan perkembangan anak. Latar belakang pendidikan 
ibu, keadaan fisik dan mental, kemampuan ibu untuk mempraktikkan dalam kehidupan seharihari serta dukungan keluarga berakumulasi dalam bentuk tumbuh kembang anak ${ }^{1}$.

Pertumbuhan yang baik ditandai dengan kesesuaian antara umur anak dengan berat badan, sedangkan perkembangan anak ditandai dengan kesesuaian antara umur anak dan jenis keterampilan yang harus dikuasai anak sesuai tahap perkembangannya. Tingkat perkembangan anak balita meliputi keterampilan dan kecerdasan yang dimiliki seorang anak sebagai hasil perkembangannya. Tingkat perkembangan setiap fase berbeda sesuai umur, ditunjang faktor lingkungan dan proses belajar ${ }^{2}$.

Praktik perawatan anak (child care) berbeda antar daerah. Namun kebutuhan anak terhadap makanan, kesehatan, perlindungan dan kasih sayang adalah universal. Perubahan dan adaptasi dalam proses pengasuhan anak dalam keluarga terjadi karena proses urbanisasi, peningkatan peranan wanita dalam ekonomi, keluarga dan pendidikan lebih tinggi ${ }^{1}$.

Penelitian di Haiti menunjukkan faktor yang memengaruhi kualitas perawatan anak dapat dibedakan secara langsung dan tidak langsung, meliputi faktor demografi, sosial ekonomi, ketahanan pangan dalam keluarga dan sumbersumber lain yang mendukung perawatan anak. Karakteristik keluarga meliputi jumlah anggota keluarga, usia kepala keluarga perbedaan umur, jenis kelamin, anggota keluarga yang bekerja dan sanitasi lingkungan ${ }^{3}$.

Keadaan gizi balita merupakan salah satu tolak ukur keberhasilan pembangunan kesehatan. Sejak tahun 1960-an Pemerintah telah melaksanakan kegiatan perbaikan gizi keluarga yang dikenal dengan Applied Nutrition Program, selanjutnya pada tahun 1974 program tersebut dikembangkan di seluruh Indonesia sebagai Program Usaha Perbaikkan Gizi Keluarga (UPGK), dimana UPGK memberikan pendidikan gizi praktis kepada keluarga melalui pemantauan pertumbuhan balita di posyandu, dan paket pelayanan kesehatan dasar secara menyeluruh ${ }^{4}$.

Masalah gizi berhubungan dengan aspek kesehatan, masalah sosial, ekonomi, lingkungan, sikap dan perilaku. Untuk mewujudkannya diperlukan seorang motivator dalam keluarga yang memiliki pengetahuan serta bersedia melakukan perubahan agar berperilaku gizi yang baik. Pengetahuan dan pendidikan dasar ibu merupakan faktor penting dalam pemenuhan kecukupan makanan bagi bayi dan balita. Pendidikan yang tinggi akan memudahkan penyerapan informasi dan pengetahuan mengenai cara pemberian makanan pada bayi dan anak ${ }^{5}$. Faktor yang memengaruhi status gizi ada dua,yaitufaktor langsung dan tidak langsung. Faktor langsung ditentukan oleh asupan makanan dan penyakit infeksi, sedangkan faktor tidak langsung meliputi ketersedian makanan dalam keluarga, pola asuh anak, pelayanan kesehatan dan kondisi lingkungan ${ }^{5}$.

Di Indonesia status gizi kurang pada balita $28 \%$ dan gizi buruk $8,8 \%$ dari 18.000 .000 balita di Indonesia ${ }^{5}$. Berdasarkan data dari Dinas Kesehatan Kota Depok angka balita penderita gizi buruk tergolong tinggi yakni 289 balita, namun angka tersebut turun $30 \%$ dari tahun sebelumnya. Kelurahan Kampung Lio dan Kecamatan Pancoran Mas merupakan daerah dengan kasus anak balita menderita gizi buruk paling banyak di Kota Depok ${ }^{6}$. Data dari Puskesmas Kecamatan Pancoran Mas menunjukkan dari 6.681 balita yang ditimbang, tercatat balita yang menderita gizi buruk 14 balita, gizi kurang 320 balita, gizi baik 6282 balita, gizi lebih 65 balita ${ }^{6}$.

Tujuan penelitian ini adalah untuk mengetahui hubungan pola asuh ibu dengan status gizi balita di Puskesmas Kecamatan Pancoran Mas, Depok.

\section{Metode}

Subjek dalam penelitian ini adalah ibu balita yang memiliki anak usia dibawah lima tahun di wilayah Kecamatan Pancoran Mas dengan kriteria anak balita tidak lebih dari 3 orang (anak termuda dijadikan sampel) dan minimal 3 bulan terakhir datang ke Posyandu. Pemilihan sampel dilakukan secara simple random sampling. Untuk menghitung besar sampel menggunakan software Sampel size Determination in Health studies versi 2.0 dan diperoleh sampel 119 ibu balita. Penelitian dilaksanakan di 4 posyandu yang ada di wilayah kerja Puskesmas Kecamatan Pancoran Mas yaitu 2 posyandu di Kelurahan Depok selama bulan Juni 2011.

Data yang digunakan merupakan data primer yang dikumpulkan melalui kuesioner dan daftar pertanyaan terstruktur. Kuesioner terstruktur berisi pertanyaan terbuka dan tertutup yang disusun menurut variabel yang diteliti. Kuesioner status gizi didapatkan dari data umur dan berat badan pada saat dilakukan penelitian di masing-masing posyandu. Kuesioner pola asuh diadopsi dari CEBU-RSUP dr. Sardjito Yogyakarta, meliputi praktik cara memberi makan, praktik cara merawat bayi dan praktik menjaga kebersihan ibu dan balita ${ }^{7}$. Kuesioner 
pengetahuan ibu tentang gizi dan makanan berupa daftar pertanyaan untuk mengukur pemahaman ibu tentang gizi dan makanan.

Hubungan antara variabel bebas dengan variabel terikat akan dianalisis menggunakan uji chi-square sedangkan untuk mengetahui hubunngan variabel bebas secara bersama-sama dengan variabel terikat digunakan analisis regresi logistik dengan tingkat kemaknaan $p<0,05$.

Hasil

Tabel 1. Distribusi Frekuensi Status Gizi Balita di Puskesmas Kecamatan Pancoran Mas Depok Tahun 2011

\begin{tabular}{lccc}
\hline & Variabel & Frekuensi (n) & Persentase (\%) \\
\hline Status gizi & & \\
Kurang & 32 & 26,9 \\
Baik & 87 & 73,1 \\
\hline
\end{tabular}

Tabel 1 menunjukkan ibu yang memiliki balita dengan status gizi kurang 26,9\%.

Tabel 2. Distribusi Frekuensi Pola Asuh Ibu di Puskesmas Kecamatan Pancoran Mas Depok Tahun 2011

\begin{tabular}{lcc}
\hline \multicolumn{1}{c}{ Variabel } & Frekuensi (n) & Persentase (\%) \\
\hline Praktik memberi makan & 53 & 44,5 \\
Kurang Baik & 66 & 55,5 \\
Baik & & \\
\hline Praktik merawat balita & 49 & 41,2 \\
Kurang Baik & 70 & 58,8 \\
Baik & & \\
\hline Praktik kebersihan ibu dan balita & 48 & 40,3 \\
Kurang Baik & 71 & 59,7 \\
Baik & & \\
\hline Pendidikan & 63 & 52,9 \\
Rendah & 56 & 47,1 \\
Tinggi & & 20,2 \\
\hline Pekerjaan & 24 & 79,8 \\
Bekerja & 95 & 68,9 \\
Tidak Bekerja & & 31,1 \\
\hline Status Ekonomi & 82 & \\
Rendah & 37 & 55,5 \\
Tinggi & & 44,5 \\
\hline Pengetahuan Ibu & 66 & \\
Kurang & 53 & \\
Baik & & \\
\hline
\end{tabular}

Berdasarkan tabel 2 diketahui bahwa ibu yang melakukan praktik memberikan makan baik pada balita $55,4 \%$ dan praktik merawat balita baik $58,8 \%$. Praktik kebersihan ibu dan balita baik 59,7\%, pendidikan rendah 52,9\%, tidak bekerja $79,8 \%$, status ekonomi rendah $68,9 \%$ dan pengetahuan kurang $55,5 \%$.

Tabel 3. Hubungan Pola Asuh Ibu dengan Status Gizi Balita di Puskesmas Kecamatan Pancoran Mas Depok Tahun 2011

\begin{tabular}{|c|c|c|c|c|c|c|c|c|}
\hline \multirow{3}{*}{ Pola Asuh Ibu } & \multicolumn{4}{|c|}{ Status Gizi } & \multirow{2}{*}{\multicolumn{2}{|c|}{ Total }} & \multirow{3}{*}{$\begin{array}{c}\text { OR } \\
(95 \% \mathrm{CI})\end{array}$} & \multirow[t]{3}{*}{$\mathrm{P}$ value } \\
\hline & \multicolumn{2}{|c|}{ Kurang } & \multicolumn{2}{|c|}{ Baik } & & & & \\
\hline & $\mathrm{N}$ & $\%$ & $\mathrm{n}$ & $\%$ & $\mathrm{n}$ & $\%$ & & \\
\hline
\end{tabular}




\begin{tabular}{|c|c|c|c|c|c|c|c|c|}
\hline \multicolumn{9}{|l|}{ Praktik Memberi } \\
\hline - Kurang baik & 16 & 30,2 & 37 & 69,8 & 53 & 100 & 1.2 & \multirow[t]{2}{*}{0.467} \\
\hline - Baik & 16 & 24,2 & 50 & 75,3 & 66 & 100 & $(0.6-2.2)$ & \\
\hline \multicolumn{9}{|l|}{$\begin{array}{l}\text { Praktik merawat } \\
\text { balita }\end{array}$} \\
\hline - Kurang baik & 19 & 38,8 & 30 & 61,2 & 49 & 100 & 2,0 & 0,014 \\
\hline - Baik & 13 & 18,6 & 57 & 81,4 & 70 & 100 & $(1,4-3,8)$ & \\
\hline \multirow{2}{*}{\multicolumn{9}{|c|}{$\begin{array}{l}\text { Praktik } \\
\text { kebersihan ibu } \\
\text { dan balita }\end{array}$}} \\
\hline & & & & & & & & \\
\hline - Kuranng baik & 10 & 20,8 & 38 & 79,2 & 48 & 100 & 0,6 & 0,220 \\
\hline - Baik & 22 & 30,9 & 49 & 69,1 & 71 & 100 & & \\
\hline
\end{tabular}

Hasil analisis menunjukkan pola asuh ibu dalam berhubungan dengan status gizi balita hal praktik merawat balita

Tabel 4. Hubungan Karakteristik Ibu dengan Status Gizi Balita di Puskesmas Kecamatan Pancoran Mas Depok Tahun 2011

\begin{tabular}{|c|c|c|c|c|c|c|c|c|}
\hline \multirow{3}{*}{ Karakteristik Ibu } & \multicolumn{4}{|c|}{ Status Gizi } & \multirow{2}{*}{\multicolumn{2}{|c|}{ Total }} & \multirow{3}{*}{$\begin{array}{c}\mathrm{OR} \\
(95 \% \mathrm{CI})\end{array}$} & \multirow[t]{3}{*}{$\mathrm{P}$ value } \\
\hline & \multicolumn{2}{|c|}{ Kurang } & \multicolumn{2}{|c|}{ Baik } & & & & \\
\hline & $\mathrm{n}$ & $\%$ & $\mathrm{n}$ & $\%$ & $\mathrm{n}$ & $\%$ & & \\
\hline \multicolumn{9}{|l|}{ Pendidikan ibu } \\
\hline - Rendah & 15 & 23,8 & 48 & 76,2 & 63 & 100 & 0.7 & 0.421 \\
\hline - Tinggi & 17 & 30,4 & 39 & 69,6 & 56 & 100 & $(0.4-1.4)$ & \\
\hline \multicolumn{9}{|l|}{ Pekerjaan ibu } \\
\hline - Tidak Bekerja & 26 & 27,4 & 69 & 72,6 & 95 & 100 & 1.0 & 0.815 \\
\hline - Bekerja & 6 & 25 & 18 & 75 & 24 & 100 & $(0.5-2.3)$ & \\
\hline \multicolumn{9}{|l|}{ Status ekonomi } \\
\hline - Rendah & 21 & 25,6 & 61 & 74,4 & 82 & 100 & 0.8 & 0.638 \\
\hline - Tinggi & 11 & 29,7 & 26 & 70,3 & 37 & 100 & $(0.4-1.5)$ & \\
\hline \multicolumn{9}{|l|}{ Pengetahuan ibu } \\
\hline - Kurang & 23 & 34,8 & 43 & 65,2 & 66 & 100 & 2.0 & 0.028 \\
\hline - Baik & 9 & 17 & 44 & 83 & 53 & 100 & $(1.0-4.0)$ & \\
\hline
\end{tabular}

Analisis bivariat menunjukkan pengetahuan ibu berhubungan dengan status gizi balita.

Tabel 5. Hubungan Karakteristik Ibu dengan Praktik Memberi Makan Balita Di Puskesmas Kecamatan Pancoran Mas Depok Tahun 2011

\begin{tabular}{|c|c|c|c|c|c|c|c|c|}
\hline \multirow[t]{3}{*}{$\begin{array}{c}\text { Karakteristik } \\
\text { ibu }\end{array}$} & \multicolumn{4}{|c|}{$\begin{array}{c}\text { Praktik Memberi Makan } \\
\text { Balita }\end{array}$} & \multirow{2}{*}{\multicolumn{2}{|c|}{ Total }} & \multirow[t]{3}{*}{$\begin{array}{c}\text { OR } \\
(95 \% \mathrm{CI})\end{array}$} & \multirow[t]{3}{*}{$P$ value } \\
\hline & \multicolumn{2}{|c|}{ Kurang Baik } & \multicolumn{2}{|c|}{ Baik } & & & & \\
\hline & $\mathrm{n}$ & $\%$ & $\mathrm{n}$ & $\%$ & $\mathrm{n}$ & $\%$ & & \\
\hline Pendidikan ibu & & & & & & & & \\
\hline - Rendah & 26 & 41,3 & 37 & 58,7 & 63 & 100 & 0.8 & 0.446 \\
\hline - Tinggi & 27 & 48,2 & 29 & 51,8 & 56 & 100 & $(0.5-1.2)$ & \\
\hline
\end{tabular}




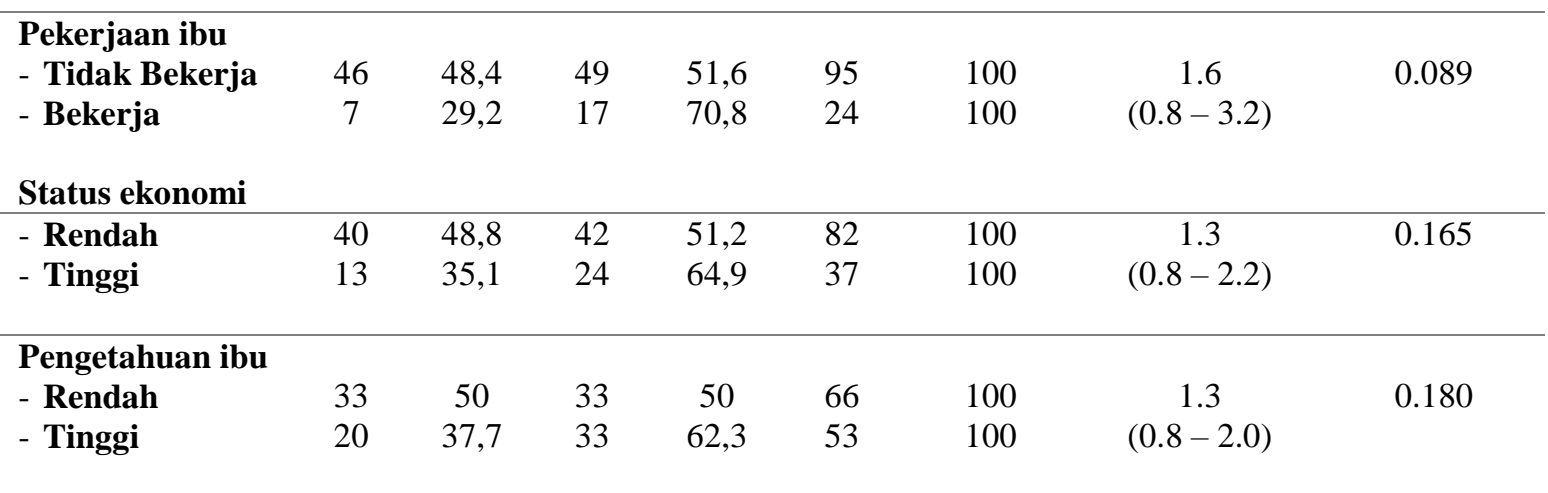

Analisis bivariat menunjukkan karakteristik ibu tidak berhubungan dengan praktik memberi makan balita.

Tabel 6. Hubungan Karakteristik Ibu dengan Praktik Merawat Balita Di Puskesmas Kecamatan Pancoran Mas Depok Tahun 2011

\begin{tabular}{|c|c|c|c|c|c|c|c|c|}
\hline \multirow{3}{*}{$\begin{array}{c}\text { Karakteristik } \\
\text { Ibu }\end{array}$} & \multicolumn{4}{|c|}{ Praktik Merawat Balita } & \multirow{2}{*}{\multicolumn{2}{|c|}{ Total }} & \multirow{3}{*}{$\begin{array}{c}\text { OR } \\
(95 \% \mathrm{CI})\end{array}$} & \multirow[t]{3}{*}{ P value } \\
\hline & \multicolumn{2}{|c|}{ Kurang Baik } & \multicolumn{2}{|c|}{ Baik } & & & & \\
\hline & $\mathrm{n}$ & $\%$ & $\mathrm{n}$ & $\%$ & $\mathrm{n}$ & $\%$ & & \\
\hline Pendidikan ibu & & & & & & & & \\
\hline - Rendah & 26 & 41,3 & 37 & 58,7 & 63 & 100 & 1.0 & 0.982 \\
\hline - Tinggi & 23 & 41,1 & 33 & 58,9 & 56 & 100 & $(0.6-1.5)$ & \\
\hline \multicolumn{9}{|l|}{ Pekerjaan ibu } \\
\hline - Tidak Bekerja & 38 & 40 & 57 & 60 & 95 & 100 & 0.8 & 0.603 \\
\hline - Bekerja & 11 & 45,8 & 13 & 54,2 & 24 & 100 & $(0.5-1.4)$ & \\
\hline \multicolumn{9}{|l|}{ Status ekonomi } \\
\hline - Rendah & 29 & 35,4 & 53 & 64,6 & 82 & 100 & 0.6 & 0.055 \\
\hline - Tinggi & 20 & 54,1 & 17 & 45,9 & 37 & 100 & $(0.4-0.9)$ & \\
\hline \multicolumn{9}{|l|}{ Pengetahuan ibu } \\
\hline - Rendah & 31 & 47 & 35 & 53 & 66 & 100 & 1.3 & 0.151 \\
\hline - Tinggi & 18 & 34 & 35 & 66 & 53 & 100 & $(0.8-2.1)$ & \\
\hline
\end{tabular}

Analisis bivariat menunjukkan tidak ada hubungan antara karakteristik ibu dengan praktik merawat balita.

Tabel 7. Hubungan Karakteristik Ibu dengan Praktik Kebersihan Ibu dan Balita Di Puskesmas Kecamatan Pancoran Mas Depok Tahun 2011

\begin{tabular}{|c|c|c|c|c|c|c|c|c|}
\hline \multirow{3}{*}{ Karakteristik Ibu } & \multicolumn{4}{|c|}{ Praktik Kebersihan Ibu \& Balita } & \multirow{2}{*}{\multicolumn{2}{|c|}{ Total }} & \multirow{3}{*}{$\begin{array}{c}\text { OR } \\
(95 \% \mathrm{CI})\end{array}$} & \multirow[t]{3}{*}{$P$ value } \\
\hline & \multicolumn{2}{|c|}{ Kurang Baik } & \multicolumn{2}{|c|}{ Baik } & & & & \\
\hline & $\mathrm{n}$ & $\%$ & $\mathrm{n}$ & $\%$ & $\mathrm{n}$ & $\%$ & & \\
\hline \multicolumn{9}{|l|}{ Pendidikan ibu } \\
\hline - Rendah & 20 & 31,7 & 43 & 68,3 & 63 & 100 & 0.6 & 0.042 \\
\hline - Tinggi & 28 & 50 & 28 & 50 & 56 & 100 & $(0.4-0.9)$ & \\
\hline \multicolumn{9}{|l|}{ Pekerjaan ibu } \\
\hline - Tidak Bekerja & 39 & 41 & 56 & 59 & 95 & 100 & 1.0 & 0.751 \\
\hline - Bekerja & 9 & 37,5 & 15 & 62,5 & 24 & 100 & $(0.6-1.9)$ & \\
\hline
\end{tabular}


Status ekonomi

$\begin{array}{lllllllll}\text { - Rendah } & 35 & 42,7 & 47 & 57,3 & 82 & 100 & 1.2 & 0.047 \\ \text { - Tinggi } & 13 & 35,1 & 24 & 64,9 & 37 & 100 & (0.7-2.0) & \\ & & & & & & & & \\ \text { Pengetahuan ibu } & & & & & & & & \\ \text { - Rendah } & 27 & 40,9 & 39 & 59,9 & 66 & 100 & 1.0 & 0.886 \\ \text { - Tinggi } & 21 & 39,6 & 32 & 60,4 & 53 & 100 & (0.6-1.6) & \end{array}$

Analisis bivariat menunjukkan status ekonomi berhubungan dengan pengetahuan ibu dalam praktik kebersihan ibu dan balita.

Tabel 8. Analisis Multivariat Hubungan Antara Praktik Memberi Makan Balita, Praktik Merawat Balita, Praktik Kebersihan Ibu dan Balita, Pengetahuan Ibu Dengan Status Gizi Balita.

\begin{tabular}{|l|c|c|}
\hline \multicolumn{1}{|c|}{ Variabel } & Model 1 & Model 2 \\
& OR $\mathbf{( 9 5 \% \mathbf { C I } )}$ & OR (95\% CI) \\
\hline Praktik Memberi Makan Balita & 1,262 & 1,156 \\
& $(0,53-2,97)$ & $(0,48-2,76)$ \\
\hline Praktik Merawat Balita & 3,185 & 2,895 \\
& $(1,32-7,66)$ & $(1,19-7,03)$ \\
\hline Praktik Kebersihan Ibu Dan Balita & 0,446 & 0,464 \\
& $(0,17-1,11)$ & $(0,18-1,16)$ \\
\hline Pengetahuan Ibu & & 2,298 \\
& & $(0,92-5,71)$ \\
\hline Deviance & 128,6 & 125,2 \\
$\mathrm{R}^{2}$ & 0,06 & 0,09 \\
$\mathrm{~N}$ & 119 & 119 \\
\hline
\end{tabular}

Tabel di atas menunjukkan ada hubungan antara praktik merawat balita dengan status gizi pada balita. Praktik merawat balita memiliki risiko 2 kali terhadap kejadian status gizi yang kurang pada balita.

\section{Pembahasan}

Berdasarkan penelitian didapatkan ibu yang memiliki balita dengan status gizi kurang $26,9 \%$. Pada prinsipnya status gizi ditentukan oleh dua hal yaitu terpenuhinya semua zat gizi dari makanan yang diperlukan oleh tubuh dan peranan faktor-faktor yang menentukan besarnya kebutuhan, penyerapan dan penggunaan zat-zat gizi tersebut. Asupan nutrisi mempunyai kaitan langsung dengan status gizi anak balita, artinya dengan asupan nutrisi yang baik akan tercipta status gizi yang baik. Tetapi penggunaan zat gizi oleh tubuh tergantung dari pencernaan serta penyerapan dan metabolisme dari zat gizi. Hal ini tergantung dari kebersihan lingkungan dan ada tidaknya penyakit yang berpengaruh terhadap penggunaan zat-zat gizi oleh tubuh tersebut ${ }^{10}$.

Variabel pola asuh diukur dengan tiga variabel yaitu praktik memberi makan balita, praktik merawat balita dan praktik kebersihan ibu dan balita. Penelitian menunjukkan ibu yang melakukan praktik memberikan makan dengan baik pada balita $55,4 \%$, praktik merawat balita dengan baik $58,8 \%$ dan praktik kebersihan ibu dan balita dengan baik 59,7\%. Karakteristik ibu sebagai pengasuh utama anak usia 12-71 bulan di daerah rural Chad Afrika, berpengaruh terhadap status gizi anak. Sebuah studi yang dilakukan di daerah perkotaan Lesotho Afrika, menunjukan bahwa pendidikan ibu memberi efek positif pada peningkatan pengetahuan tentang gizi dan kesehatan serta peningkatan kemampuan pemberian pengasuhan. Praktik pengasuhan merupakan determinan bagi status gizi anak, meskipun anak tersebut berasal dari keluarga miskin ${ }^{9,10}$.

Hasil analisis univariat hubungan antara praktik memberi makan balita dengan status gizi balita, diperoleh nilai $p=0,467$, sehingga dapat disimpulkan tidak ada hubungan yang bermakna antara praktik memberi makan dengan status gizi balita. Hasil penelitian ini berbeda dengan penelitian Husaini (2000) yang mengemukakan peran keluarga terutama ibu dalam anak akan menentukan tumbuh kembangnya. Perilaku ibu dalam memberi makan, cara makan yang sehat dan memberi makanan bergizi serta mengontrol porsi 
yang dihabiskan akan meningkatkan status gizi anak 1. Peningkatan kemampuan pola asuh ibu dalam praktik pemberian makan menyebabkan penambahan berat badan anak. Bila pertumbuhan anak adalah penambahan berat badan antara dua titik waktu, maka konklusi yang dapat dibuat yakni peningkatan kemampuan pola asuh ibu dalam praktik pemberian makan akan menyebabkan peningkatan pertumbuhan. Peningkatan kualitas pengasuhan ibu dalam praktik pemberian makan akan menyebabkan peningkatan kualitas pertumbuhan anak, sehingga anak akan bertumbuh dengan baik. Saat ini, dengan bergesernya fungsi wanita dalam rumah tangga yakni tidak hanya sebagai ibu rumah tangga, tetapi juga menjadi pencari tambahan nafkah untuk menutupi kekurangan kebutuhan ekonomi keluarga, maka hubungan beban kerja ibu dengan perawatan atau pola asuh anak di rumah yang berkaitan dengan gizi anak menjadi aspek penting bagi kesejahteraan anak dan harus mendapatkan perhatian yang serius.

Hasil analisis univariat variabel praktik merawat balita secara statistik diperoleh nilai $p=0,014$, maka dapat disimpulkan ada hubungan yang bermakna antara praktik merawat balita dengan status gizi balita. Pola pengasuhan anak berupa sikap dan praktik ibu atau pengasuh lain dalam kedekatannya dengan anak, yang meliputi, pemberian ASI, cara memberi makan kepada anak (child feeding), memberi rasa aman, melindungi anak, tidur bersama, memandikan dan memakaikan pakaian, membiasakan menggunakan toilet, merawat kebersihan, mencegah dari kuman patogen dan serangan penyakit, pencegahan dan pengobatan saat anak sakit, berinteraksi dan memberikan stimulasi, bermain bersama dan bersosialisasi, memberi kasih sayang serta menyediakan lingkungan sehat, agar anak dapat tumbuh kembang dengan baik ${ }^{11}$.

Hasil uji statistik pada variabel praktik kebersihan ibu dan balita diperoleh nilai $p=0,220$, sehingga dapat disimpulkan tidak ada hubungan yang bermakna antara praktik kebersihan ibu dan balita dengan status gizi balita. Hasil penelitian ini tidak sesuai dengan penelitian Satoto (1990), faktor kuat yang memengaruhi pertumbuhan adalah lingkungan asuh dan konsumsi makanan, terutama masukan energi, protein dan Fe. Keadaan sosial ekonomi berpengaruh pada perilaku asuhan ibu, dalam arti kesiapan budaya, sosial ekonomi dan menyediakan lingkungan asuh anak ${ }^{12}$. Praktik kebersihan ibu dan balita mencakup aspek higiene perorangan berhubungan dengan kemampuan ibu untuk menjaga kebersihan diri sendiri dan bayinya, agar tetap segar dan bersih, sehingga dapat tumbuh dengan sehat. Terdapatenam faktor yang berkaitan dengan ibu sebagai perawat bayi dan anak, yaitu 1) kesehatan ibu yang kurang baik atau buruk; 2) pendidikan rendah atau kepercayaan yang salah; 3) kesehatan mental dan kepercayaan diri yang rendah; 4) kurangnya dorongan sosial dari masyarakat, keluarga dan suami; 5) beban kerja ibu besar dan 6) kurangnya sumber daya atau rendahnya kemampuan ibu dalam mengontrol sumber daya yang tersedia ${ }^{13}$.

Hasil analisis hubungan antara pendidikan ibu dengan status gizi balita diperoleh diperoleh nilai $p=0,421$. Hasil ini menunjukkan tidak ada hubungan antara pendidikan ibu dengan status gizi balita. Hasil penelitian Jus'at, dkk., (2000) menunjukkan keadaan ibu terutama dalam hal kesehatan fisik maupun mental, status gizi, pendidikan dan pengetahuan sangat berhubungan dengan keterampilan pengasuhan anak dengan baik. Pendapat ini didukung oleh hasil penelitian Suharsi (2001) yang menyatakan pola pengasuhan ibu berkaitan erat dengan keadaan ibu terutama kesehatan, pendidikan, pengetahuan dan keterampilan tentang pengasuhan anak ${ }^{11,14}$. Sumali (1998) menyatakanbahwa proporsi anak yang berstatus gizi rendah ditemukan lebih banyak pada kelompok ibu yang berpendidikan SD dan tidak bersekolah.Tingkat pendidikan orangtua secara signifikan berhubungan dengan status kesehatan dan kesejahteraan anak menemukan bahwa tingkat pendidikan orang tua secara signifikan berhubungan dengan status kesehatan dan kesejahteraan anak. Prevalensi gizi kurang pada ibu berpendidikan rendah cenderung lebih tinggi dibanding ibu berpendidikan tinggi. Diasumsikan ibu yang terpelajar mempunyai lebih banyak ilmu pengetahuan dan kemungkinan keahlian yang lebih banyak dalam menjalankan tugasnya sebagai orangtua. Pengetahuan yang diperoleh ibu terhadap jenis makanan tertentu berpengaruh terhadap hidangan yang disiapkan oleh ibu setiap hari bagi keluarga. Keadaan ini apabila seorang ibu tidak bijaksana dalam memilih makanan untuk keluarga dapat mengakibatkan gizi kurang bagi anakanaknya ${ }^{15,16}$.

Hasil analisis hubungan pekerjaan ibu dengan status gizi balita diketahui nilai $\mathrm{p}=0,815$, maka dapat disimpulkan tidak ada hubungan yang bermakna antara pekerjaan ibu dengan status gizi balita. Gumala (2002) menyatakan ibu yang bekerja di luar rumah merupakan salah satu penyebab atau risiko yang dapat mengakibatkan ibu mempunyai pola asuh yang tidak baik pada anak. Pekerjaan responden sebagai ibu rumah tangga diharapkan dapat lebih banyak memberi waktu dalam pengasuhan bayinya. Ibu yang bekerja mempunyai 
waktu yang lebih sedikit dalam merawat balita sehingga dapat mempengaruhi status kesehatan balita tersebut. Pola pengasuhan dan dukungan yang diberikan oleh ibu pada anak berhubungan dengan keadaan kesehatan baik fisik maupun mental, status gizi $^{5,16}$.

Pada penelitian ini ditemukan status ekonomi rendah $68,9 \%$ dengan nilai $p=0,638$. Hasil ini menunjukkan tidak adahubungan yang bermakna antara status ekonomi dengan status gizi balita.Penelitian Susilowati (2002) menunjukkan, pendapatan keluarga berhubungan dengan status gizi. Seperti halnya status pendidikan, hubungan status ekonomi orang tua dan status gizi balita telah banyak diungkapkan dalam beberapa penelitian sebelumnya ${ }^{17}$. Faktor ekonomi merupakan salah satu faktor yang berkaitan dengan status kesehatan anak. Anak-anak dari keluarga miskin tidak mendapatkan intake makanan yang cukup, dan dalam jangka waktu lama akan menyebabkan kurang gizi. Faktor lain yang memperberat kondisi ini adalah infeksi dan sanitasi lingkungan yang buruk.Hubungan status gizi anak dengan pendapatan keluarga berdasarkan perbedaan jumlah anggota keluarga, bahwa semakin tinggi pendapatan dan semakin rendah jumlah anggota keluarga, semakin baik pertumbuhan anak. Menurut Susenas 2004 keluarga dengan jumlah anggota 3 orang atau kurang mengalami prevalensi KEP (29.3\%) dan tertinggi pada rumah tangga dengan anggota 10 orang atau lebih (31.5\%). Kejadian gizi kurang dan gizi buruk lebih banyak terjadi pada anak-anak dari keluarga miskin, akibat dari asupan makanan yang tidak mencukupi. Hal ini diperberat dengan sanitasi yang buruk dan penyakit 18 . Dilihat dari status ekonomi pendapatan keluarga di daerah penelitian sebagian besar tergolong rendah berdasarkan UMR Kota Depok. Standar upah minimum tersebut diharapkan dapat memenuhi kebutuhan hidup minimum seorang pegawai dengan layak. Pendapatan merupakan faktor penting bagi kuantitas dan kualitas makanan. Peningkatan penghasilan berpengaruh terhadap perbaikan kesehatan dan kondisi keluarga lain yang berinteraksi terhadap status gizi. Tingkat pendapatan menentukan jenis pangan yang akan dibeli. Semakin tinggi pendapatan semakin besar pula persentase dari penghasilan tersebut digunakan untuk membeli bahan pangan. Walaupun bahan pangan dalam keluarga berkualitas, tidak ada jaminan bahwa pangan tersebut dapat diterima oleh mereka yang paling memerlukan gizi dalam keluarga dalam hal ini balita. Kemiskinan merupakan akar masalah timbulnya gizi kurang, dengan kemiskinan asupan makanan berkurang dan munculah berbagai macam penyakit. Selain itu asupan makanan dipengaruhi juga oleh faktor sosial budaya.

Hasil analisis hubungan pengetahuan ibu dengan status gizi balita diketahui nilai $p=0,028$, dapat disimpulkan ada hubungan yang bermakna antara pengetahuan ibu dengan status gizi balita. Tingkat pengetahuan gizi seseorang berpengaruh terhadap sikap dan perilaku dalam pemilihan makanan dan selanjutnya akan berpengaruh pada keadaan gizi yang bersangkutan. Ibu yang memiliki pengetahuan baik tentang adanya makanan khusus tersebut serta mengusahakan agar makanan khusus tersebut tersedia untuk dikonsumsi anaknya cenderung mempunyai bayi atau anak dengan keadaan gizi baik ${ }^{11}$. Pengetahuan dan pendidikan dasar ibu merupakan faktor penting dalam pemenuhan kecukupan makanan bagi bayi dan balita. Pendidikan umum yang lebih tinggi akan memudahkan penyerapan informasi dan pengetahuan mengenai cara pemberian makanan pada bayi dan anak serta adanya kebiasaan yang merugikan kesehatan secara langsung dan tidak langsung menjadi penyebab utama terjadinya masalah gizi pada balita khususnya di bawah dua tahun ${ }^{5}$. Semakin buruk pengetahuan ibu tentang gizi maka akan semakin buruk pula status gizi anaknya. Pada umumnya penyelenggaraan makanan dalam rumah tangga sehari-hari dikoordinir oleh ibu. Ibu yang mempunyai pengetahuan gizi dan kesadaran gizi yang tinggi akan melatih kebiasan makan yang sehat sedini mungikin kepada putraputrinya. Anak-anak biasanya meniru apa yang dilakukan oleh orang tuanya atau kakak-kakaknya. Bila anak melihat anggota keluarga yang lain mau makan apa yang dihidangkan ibu di meja makan ia pun akan ikut makan juga. Jelas disini bahwa ibu berperan penting dalam melatih anggota keluarganya dalam membiasakan makan yang sehat 19 .

\section{Kesimpulan}

Praktik merawat balita dan pengetahuan ibu berpengaruh terhadap status gizi balita. Tidak ditemukan hubungan bermakna antara praktik memberi makan, praktik kebersihan ibu dan balita, pendidikan ibu, pekerjaan ibu dan status ekonomi dengan kejadian gizi kurang. Faktor lain yang berpengaruh lansung terhadap status gizi adalah asupan nutrisi.

\section{Saran}

Mendukung praktek merawat balita yang baik perlu adanya stimulan bagi ibu mengenai program gizi dan kesehatan berupa informasi dan pemberdayaan ibu di posyandu dan lembaga lainnya yang berkaitan dengan institusi kesehatan. Ibu 
hendaknya membudayakan gizi seimbang dalam penyelenggaraan makanan sehari-hari sehingga pengaruh gaya hidup yang negatif perlu dikendalikan.

\section{Daftar Pustaka}

Husaini ,M. Peranan Gizi dan Pola Asuh dalam meningkatkan Kualitas Tumbuh Kembang Anak. Medika .Badan Penelitian Pengembangan Kesehatan. Jakarta. 2000.

Ismail, Dj. Tumbuh Kembang Anak. Materi Pelatihan Deteksi Dini Pentimpangan dan Pemantauan Tumbuh Kembang Anak.RSUP.DR.Sardjito. Yogyakarta. 1997.

Mc.Lanahan, Sara and Booth, Karen. Mother Only Families : Problem, Propects and Politics. Journal of Marriage and The Family. 1989. 55 : 481-493

Kurniawan, A. Policies in Alleviating Micronutrient Deficiencies: Indonesia” Experience. Asia Pasific Journal Clinical Nutrition. Directorate of Community Nutrition, Ministry of Health, Republic Indonesia, Jakarta. 2002.

Depkes R.I, Rencana Aksi Pangan dan Gizi Nasional (National Plan of Action Food and Nutrition,2001-1005). 2000.

Puskesmas Kecamatan Pancoran Mas, Laporan Tahunan 2010 Seksi Gizi Puskesmas Kecamatan Pancoran Mas. Depok : Puskesmas Kecamatan Pancoran Mas. 2010.

Suharsi, Hubungan Pola Asuh Ibu dan Penyakit Infeksi dengan Anak Balita Gizi Buruk Di Kabupaten Demak Provinsi Jawa Tengah. Yogyakarta : Universitas Gajah Mada. 2000.

Soekirman, Ilmu Gizi dan Aplikasinya Untuk Keluarga dan Masyarakat. Jakarta. Direktorat Bina Gizi Masyarakat. 2000.

Bringham, Social Psyhcology, 9 nd edition, New York, Harper Collin Publisher Inc. 1997.

Sarwono, S., Sosiologi Kesehatan, Beberapa Konsep Aplikasinya. Yogyakarta : Gadjah Mada University Press. 2004.

Kotch, MD, Jonathan. Maternal and Child Health. Departemen of Maternal and Child Health The University of North Carolina at Chapel Hill. Chapel Hill, North Carolina. 1997.

Drewnoski A and Popkin B.M The Nutrition Transition : New Trend in Global Diet. 1997. Nutrition Review, $55: 31$ - 43
Ali , M., Asefaw,T., Byass,P., Beyene,H., Karup.F, Helping Northern Ethiopian Communities Reduce Childhood Mortality: Population Based Intervention Trial,The Journal Of Public Health, 2005. 83(1)pp27-33

Yuli Indarti, Hubungan Status Kehadiran Orang tua Dalam Keluarga dengan Status Gizi Balita Di Indonesia Analisis Data. 2004.

Sumali,MA., Studi Analisis Faktor- Faktor yang Mempengaruhi Status Gizi Anak Balita di Kabupaten Purworedjo Jawa Tengah, Laboratorium Kesehatan dan Gizi Masyarakat, FK-UGM, Yogyakarta. 1998.

Tarigan Faktor-faktor Yang Berhubungan Dengan Status Gizi Anak Umur 6-36 Bulan Sebelum Dan Saat Krisis Ekonomi Di Jawa Tengah.Buletin Penelitian Kesehatan. 2003. Vol.31 hal.1-12.

Karyadi, Susilowati. Malnutrition And Poverty Alleviaton. Asia Pacific Journal Clinical Nutrition. 2002. pp 323-330

Nandy,S., Irving.M., Gordon.D., Subramanian,SV., Davey,G, Poverty, Chlid Undernutrition Ang Morbidity: New Evidance From India, The Journal Of Public Health,83(1),pp210-216

Waryana. Pengaruh Perilaku Ibu Terhadap Kejadian Kurang Energi Dan Protein Anak Balita Di Kecamatan Imogiri Kabupaten Bantul Propinsi $D I Y$. Nutrisia. 2004. Vol.5 hal. 65-70. 